\title{
New Attachment Formation Following Periodontal Surgery in a Dog
}

\author{
Hamit Selim BOSTANCI ${ }^{1}$, \\ Mehmet Nejat ARPAK ${ }^{1}$ and Ömer GÜNHAN ${ }^{2}$
}

(Received 19 February and accepted 6 March 1990)

Key words: experimental periodontitis, periodontal regeneration, surface demineralization, oral hygiene

\begin{abstract}
We evaluated new attachment following treatment of experimental periodontitis in a canine model. Periodontal destruction was induced over an 8-month period using silk ligatures and a soft diet, and this remained stable for 170 days before surgery. After surgical scaling and root planing of eight bicuspid teeth, the apical end of the pockets was estimated using an occlusal stent and a periodontal probe, then marked with a blade. The root surfaces of three bicuspids were treated with citric acid for $3 \mathrm{~min}$, and tetracycline salt was applied to the root surfaces of two teeth. The remaining three bicuspids served as controls. Postoperatively, no attempts were made to improve oral hygiene, and on day 48 light microscopic examination of biopsy materials revealed new attachment in all treated teeth. However, in some sections new cementum and new collagen formation was much more extensive and complete in both groups of experimental teeth than in the control teeth.
\end{abstract}

\section{Introduction}

The possibility of restoring periodontal tissues lost as a result of periodontal pathology has been the subject of various studies. Such restoration is known as "new attachment" or "complete regeneration." Attempts to achieve new attachment involve preparation of the root surface previously related to the periodontal pocket in such a way that it becomes biologically more conducive for induction of connective tissue.

Increased activity of bone and connective tissue formation using different materials, and delay of apical migration of the gingival epithelium, establishing a connection between the root and connective tissue at a more coronal level during healing, have been reported so $\mathrm{far}^{[1-3]}$. Recently, the root surface has received a great deal of attention, and studies aimed at activating the connection of fibrin to cementum and dentin at the surgical site have been widely performed ${ }^{[4-7]}$. Citric

1 Department of Periodontology, Faculty of Dentistry, Ankara University

2 Department of Pathology, Gülhane Military Medical Academy

To whom all correspondence should be addressed: Assoc. Prof. Hamit Selim BOSTANCI, A. Ü. Diş

Hekimliği Fakültesi Periodontoloji Anabilim Dali, 06500 Beşevler, Ankara, TURKEY 
acid is the chemical agent used most commonly for this purpose.

Although the results of some studies suggest that it is biologically possible to establish new attachment using this demineralization procedure, which is also called "chemical root treatment," other experimental studies performed in man and animals have given contradictory results ${ }^{[4,8-11]}$. Therefore, the aim of this study was to investigate further the concept of new attachment and to evaluate the results using a canine model.

\section{Materials and Methods}

One dog was used for the present study. Chronic periodontal tissue destruction was created without surgical traumatization. For this purpose, silk ligatures were placed on the bicuspid teeth of the upper and lower jaws and the dog was given a soft diet to induce plaque formation. After 8 months, the silk ligatures were removed and the soft diet withdrawn. Two months later, subgingival curettage was performed on the right segments of the upper and lower jaws. Then, 110 days after the curettage, a flap operation was carried out. Root planing was performed on all teeth using Gracey curettes. For eight bicuspid teeth in four segments, pocket bases were estimated by means of an occlusal stent and a periodontal probe and then marked with a scalpel blade on the cementum of the midradicular surface. The root surfaces of three bicuspids were treated with fresh saturated citric acid solution ( $\mathrm{pH} \mathrm{1}$ ) for $3 \mathrm{~min}$ and washed with physiological saline for $1 \mathrm{~min}$. Tetracycline $\mathrm{HCl}$ salt was applied to the root surfaces of two other teeth. The remaining three bicuspids were left as controls. Flaps were replaced and sutured interdentally using 3-0 silk suture. One week later, the sutures were removed. Postoperatively, no attempts were made to improve oral hygiene and after 48 days, the dog was sacrificed using a lethal dose of IV sodium pentothal solution and block sections of the teeth were taken. Fixation of the material in $10 \%$ neutral buffered formalin solution was followed by decalcification with citrate-buffered 5\% formic acid solution. Midradicular sections were stained with hematoxylin and eosin and evaluated by light microscopy.

The teeth in the treated segments and the procedures performed are shown in Fig. 1.

\section{Results}

The periodontal tissue destruction obtained within 8 months using silk ligatures and a soft diet was found to be irreversible both clinically and radiographically after 10 months and at the time of the flap operation after 13 months. During the operation, left segments demonstrated the full characteristics of chronic periodontitis, with large amounts of calculus and plaque within the gingival pockets. On the other hand, the right segments demonstrated increased pocket depth but were otherwise clinically healthy.

Histopathologic examination of the gingival tissue on day 48 after the flap operation showed subepithelial inflammatory cell infiltration in all sections. New cementum and connective tissue attachment were found spread in a coronal direction along the root surface over the reference points in sections of teeth 
treated with citric acid, although new connective tissue attachment was not always seen together with new cementum formation (Fig. 2).

In sections of teeth treated with tetracycline salt, fine, newly formed cementum and fairly extensive new connective tissue attachment were observed (Fig. 3). New cementum and connective tissue attachment were also seen in sections of the control teeth (Fig. 4), although the new cementum was limited to the reference sites in some sections and the new connective tissue attachment was shorter than in both types of experimental teeth.

\section{Discussion}

It has been shown in earlier studies that new connective tissue attachment can be obtained on the root surfaces of previously diseased teeth ${ }^{[12,13]}$. Studies to find the optimum conditions of the root surface to induce connective tissue responses have been carried out ${ }^{[14,15]}$ and new therapeutic techniques have been developed $^{[16,17)}$. On the other hand, there is some doubt surrounding animal experiments, since animal models have different characteristics from man, and the results cannot be reproduced in humans $s^{[4,9,11,18]}$. However, because simulation of standard experimental conditions is impossible in man, and various difficulties are encountered in histological investigations, animal models will continue to be in demand for a long time.

In addition to the inflammatory characteristics observed in animals, irreversibility of any artificial defects is also an important consideration. The method we used in this study, involving interference with the relation between soft tissue resistance and plaque formation, seems to be more appropriate for this purpose, even though it requires a long period. It has been noted that especially in dogs, it is not appropriate to develop defects in a short time with regard to the criteria mentioned above ${ }^{[19]}$. Furthermore, it is clear that there is a need for additional manipulation and time in order to increase plaque formation and obtain a chronic inflammatory state after development of a mechanical defect ${ }^{[20]}$. We found that the defects created artificially by this method were irreversible, both clinically and radiographically. The destruction did not progress, however, and the defect remained stable after removal of the ligatures. These results are in agreement with a previously published study by LINDHE and ERICSSON ${ }^{[21]}$.

Investigations evaluating the level of new attachment by histologic and histometric analysis require appropriate reference points. If calculus is present in the pocket, marking of its most apical point is a widely accepted procedure ${ }^{[22,23]}$. In the present study, due to the absence of calculus on the right segments, pathological pocket bases were estimated using an occlusal stent during surgery. Because of the scarcity of our material, the results were evaluated by comparison, without histometric analysis.

As is well known, the amount of new attachment which can be obtained in a deep periodontal pocket is greater than that in a pocket of medium depth, whereas loss of attachment can occasionally be observed within a shallow periodontal pocket. Therefore, in this study care was taken to include pockets of similar depth for the experimental and control teeth. We found that both new 
cementum formation and new connective tissue attachment on the previously diseased root surfaces were present in all teeth. However, in some sections the level of new attachment was higher in teeth treated with citric acid than in the control teeth. These findings are in accordance with the results of GARA and ADAMS ${ }^{[6]}$, who reported that new attachment was biologically possible following demineralization by citric acid in dogs. On the other hand, our findings contradict the results of CRIGGER et al. and Nilveus et al. ${ }^{[24,25]}$, who reported that citric acid treatment was a prerequisite for the formation of new attachment. In our study, it was observed that new attachment formation was also possible biologically in teeth which had not been treated with citric acid.

Tetracycline is one of the most useful chemicals in periodontics, and various forms of tetracycline are used for different purposes in periodontal therapy. In our study, we observed that topical application of the salt form of tetracycline during surgery had no effect on new attachment formation. According to the recent findings of others, the collagenase inhibitory and acidic effects of tetracyclines should widen their use in periodontics ${ }^{[26-28]}$.

In this study, we made no efforts to maintain oral hygiene during the postoperative period. Histopathologically, this resulted in presence of subepithelial inflammatory infiltration in all sections. Similar results were also obtained by VAN $D_{I J K}{ }^{[19]}$ in 1979 . He reported that in dogs for which oral hygiene measures were not taken during the postoperative period, new cementum and connective tissues were still present, although maturation of these tissues was not complete 2 years after the operation. Together with our results and those of Van Dijk, it can be concluded that new attachment in dogs is mainly the result of the surgical procedure used, and that maintenance of oral hygiene is important in terms of quality and continuation of the histology obtained by surgical treatment. As has been shown by CORBA et al. ${ }^{[29]}$, oral hygiene is necessary for the health of gingival tissue after creation of experimental defects in dogs, since it has already been reported that in dogs, healing takes place in deep parts of the lesion after removal of the ligatures, which alone can cause subgingival plaque formation ${ }^{[20,30]}$. In contrarst, it has been proved in man that loss of attachment takes place after periodontal surgery if oral hygiene is not maintained ${ }^{[31]}$, and thus plaque control programs are recommended ${ }^{[32,33]}$.

The results of the present study and of previously reported investigations indicate that the differences between the wound healing process of experimental periodontal defects in both canine and human periodontal disease must be taken into consideration for further clinical application of regeneration procedures in man.

\section{References}

[1] Bowers, G. M., Granet, M., Stevens, M., Emerson, J., Corio, R., Mellonig, J., Lewis, S. B., Peltzman, B., Romberg, E. and Risom, L.: Histologic evaluation of new attachment in humans, J. Periodontol., 56, 381-396, 1985

[2] Caton, J., Nyman, S. and $Z_{\text {Ander, }}$ H.: Histometric evaluation of periodontal surgery: II. Connective tissue attachment levels after four regenerative procedures, J. Clin. Periodont., 7, 224-231, 1980 
[3] Ellegatad, B., Karring, T. and Loe, H.: Retardation of epithelial migration in new attachment attempts in intrabony defects in monkeys, J. Clin. Periodont., 3, 23-37, 1976

[4] Cole, R. T., Nilveus, R., Ainamo, J., Bogle, G., Crigger, M. and Egelberg, J.: Pilot clinical studies on the effect of topical citric acid application on healing after replaced flap surgery, J. Periodont. Res., 16, 117-122, 1981

[5] Crigger, M., Renvert, S. and Bogle, G.: The effect of topical citric acid application on surgically exposed periodontal attachment, J. Periodont. Res., 18, 303-305, 1983

[6] Gara, G. G. and Adams, D. F.: The effect of notching and citric acid on healthy root surfaces in dogs, J. Periodont. Res., 19, 100, 1984

[7] Lopez, N. J.: Connective tissue regeneration to periodontally diseased roots, planed and conditioned with citric acid and implanted into the oral mucosa, J. Periodontol., 55, 381-390, 1984

[8] Gotrlow, J., Nyman, S. and KarRing, T.: Healing following citric acid conditioning of roots implanted into bone and gingival connective tissue, J. Periodont. Res., 19, 214, 1984

[9] Kashani, H. G., MAGNer, A. W. and STAHL, S. S.: The effect of root planing and citric acid application on flap healing in humans. A histologic evaluation, J. Periodontol., 55, 679-683, 1984

[10] Nyman, S., Lindhe, J. and Karring, T.: Healing following surgical treatment and root demineralisation in monkeys with periodontal disease, J. Clin. Periodont., 8, 249-258, 1981

[11] Renvert, S. and EGelberg, J.: Healing after treatment of periodontal intraosseous defects. II. Effect of citric acid conditioning of the root surface, J. Clin. Periodont., 8, 459-473, 1981

[12] K Kinge, B., Nilveus, R., Kiger, R. D. and E Eelberg, J.: Effect of flap placement and defect size on healing of experimental furcation defects, J. Periodont. Res., 16, 236-248, 1981

[13] Polson, A. M. and PRoYe, M. D.: Effect of root surface alterations on periodontal healing. II. Citric acid treatment on the denuded root, J. Clin. Periodont., 9, 441-454, 1982

[14] Karring, T., Nyman, S. and Lindhe, J.: Healing following implantation of periodontitisaffected roots into bone tissue, J. Clin. Periodont., 7, 96-105, 1980

[15] Karring, T., Nyman, S., Lindhe, J. and Sirirat, M.: Potentials for root resorption during periodontal healing, J. Clin. Periodont., 11, 41-52, 1984

[16] Magnusson, I., B Btick, C. and Collins, B. R.: New attachment formation following controlled tissue regeneration using biodegradable membranes, J. Periodontol., 59, 1-6, 1988

[17] Tanner, M. G., Solt, C. W. and Vuddhakanok, S.: An evaluation of new attachment formation using microfibrillar collagen barrier, J. Periodontol., 59, 524-530, 1988

[18] Ericsson, I., Lindhe, J., Liljenberg, B. and Persson, A. L.: Lack of bacterial invasion in experimental periodontitis, J. Clin. Periodont., 14, 478-485, 1987

[19] Van DIJK, L. J.: Surgery and oral hygiene on artificial periodontal defects in beagle dogs, Thesis, Groningen, 1979

[20] Hugoson, A. and SCHмid, G.: Influence of plaque control on the healing of experimentally induced bone defects in the dog, J. Periodontol., 49, 135-141, 1978

[21] LINDHE, J. and ERICSSON, I.: Effect of ligature placement and dental plaque on periodontal tissue breakdown in the dog, J. Periodontol., 49, 343-350, 1978

[22] Cole, R. T., Grigger, M., Bogle, G., Egelberg, J. and Selvig, K. A.: Connective tissue regeneration to periodontally diseased teeth, J. Periodont. Res., 15, 1-9, 1980

[23] Steiner, S. S., CRIGger, M. and EGelberg, J.: Connective tissue regeneration to periodontally diseased teeth. II. Histologic observations of cases following replaced flap surgery, $J$. Periodont. Res., 16, 109-116, 1981

[24] Crigger, M., Bogle, G., Nilveus, R., Egelberg, J. and Selvig, K. A.: The effect of citric acid application on the healing of experimental furcation defects in dogs, J. Periodontal Res., 13, 538-549, 1978

[25] Nilveus, R., Bogle, G., CRigger, M., Egelberg, J. and Selvig, K. A.: The effect of topical citric acid application on the healing of experimental furcation defects in dogs. II. Healing after repeated surgery, J. Periodont. Res., 15, 544-550, 1980

[26] G olub, L. M., G oodson, J. M., Lee, H. M., V idal, A. M., McN amara, T. F. and Ramamurthy,N. S.: Tetracyclines inhibit tissue collagenases effects of ingested low-dose and 
local delivery systems, J. Periodontol., 56 (Suppl.), 93-97, 1985

[27] Terranova, V. P., Franzetti, L. C., Hic, S., DiFlorio, R. M., Lyall. R. M., Wikesjö, U. M. E., Baker, P. J., Christerson, L. A. and Genco, R. J.: A biochemical approach to periodontal regeneration: Tetracycline treatment of dentin promotes fibroblast adhesion and growth, J. Periodont. Res., 21, 330-337, 1986

[28] Claffet, N., Bogle, G., Bjorvatn, K., Selvig, K. A. and Egelberg, J.: Topical application of tetracycline in regenerative periodontal surgery in beagles, Acta Odontol. Scand., 45, 141-146, 1987

[29] Corba, N. H. C., Jansen, J. and Pilot, T.: Artificial periodontal defects and frequency of toothbrushing in beagle dogs. II. Clinical findings after a period of healing, J. Clin. Periodont., 13, 186-189, 1986

[30] J J ligature removal, J. Periodont. Res., 18, 262-276, 1983

[31] Nyman, S., Lindhe, J. and Rosling, B.: Periodontal surgery in plaque infected dentitions, $J$. Clin. Periodont., 4, 240-249, 1977

[32] Lindhe, J. and Nyman, S.: The effect of plaque control and surgical plaque elimination on the establishment and maintenance of periodontal health. A longitudinal study of periodontal therapy in case of advanced disease, J. Clin. Periodont., 2, 67-79, 1975

[33] Ramfjord, S. P., Knowles, J. W., Nissle, R. R., Burgett, F. G. and Shick, R. A.: Results following three modalities of periodontal therapy, J. Periodontol., 46, 522-526, 1975 


\begin{tabular}{|c|c|c|c|}
\hline \multicolumn{2}{|c|}{$(\mathrm{CA})$} & \multicolumn{2}{|c|}{$(\mathrm{T})$} \\
\hline P4 & P3 & P3 & $\mathrm{P} 4$ \\
\hline P4 & P3 & P3 & $\mathrm{P} 4$ \\
\hline (CA & & $(\mathrm{T})$ & $(\mathrm{CA})$ \\
\hline
\end{tabular}

Fig. 1 The teeth in the treated segments and the procedures performed. T: Tetracycline $\mathrm{HCl}$. CA: Citric acid. P: Bicuspid.

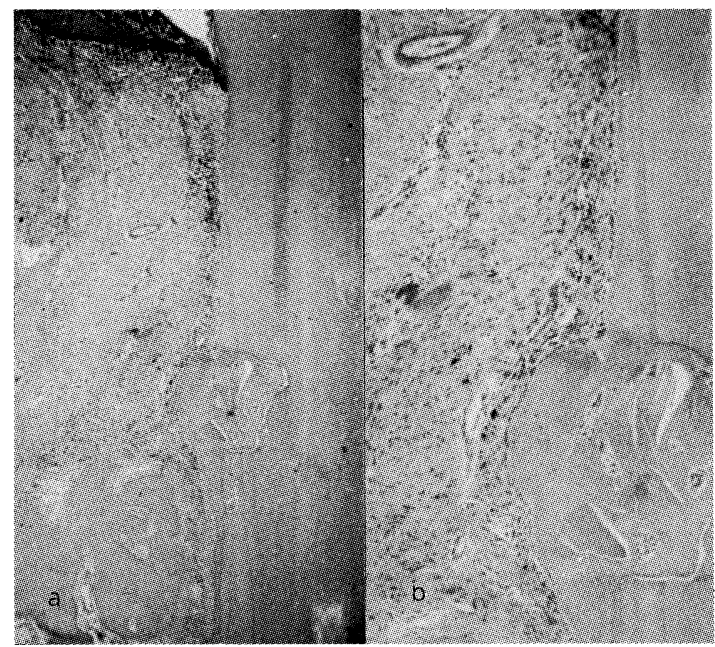

Fig. 2 Citric acid-treatd specimen. (a) Subepithelial infiltrate and new attachment formation is visible. (b) New cementum and connective tissue formation on previously diseased surface. 


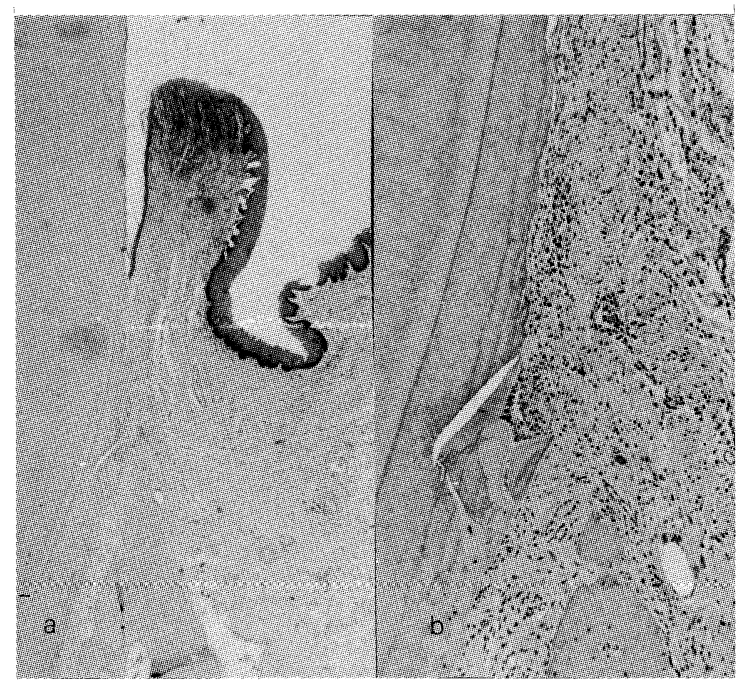

Fig. 3 Tetracycline-treated specimen. (a) New attachment on root surface. (b) New cement formation is limited to notch region.

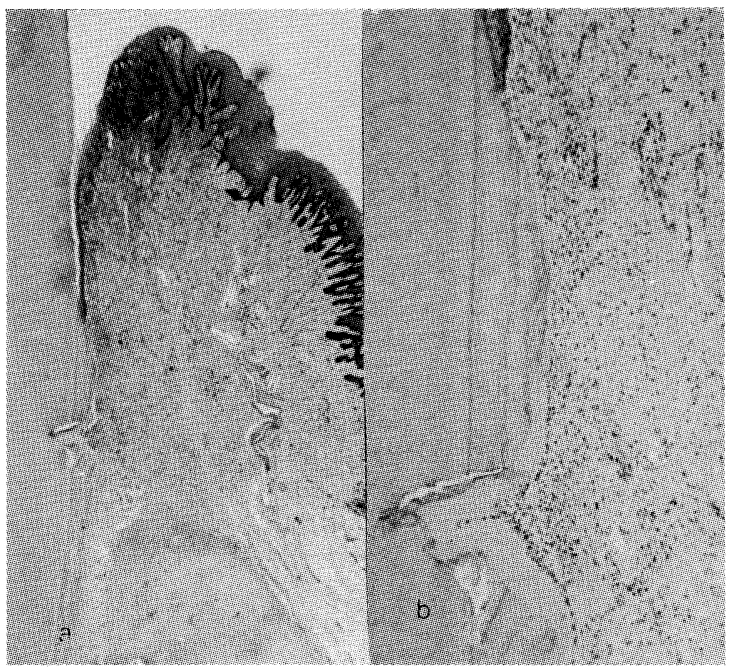

Fig. 4 Control specimen. (a,b) New cement and connective tissue formation can be seen on root surface. 